\title{
A decrease in vitamin $D$ levels is associated with methotrexate-induced oral mucositis in children with acute lymphoblastic leukemia
}

\author{
N. Oosterom ${ }^{1,2,3} \cdot$ N. F. Dirks ${ }^{4} \cdot$ S. G. Heil ${ }^{2} \cdot$ R. de Jonge ${ }^{5} \cdot$ W. J. E. Tissing ${ }^{6} \cdot$ R. Pieters ${ }^{1}$ • \\ M. M. van den Heuvel-Eibrink ${ }^{1}$ - A. C. Heijboer ${ }^{4,7}$. S. M. F. Pluijm ${ }^{1,8}$
}

Received: 27 February 2018 / Accepted: 6 June 2018 / Published online: 19 June 2018

(C) The Author(s) 2018

\begin{abstract}
Purpose Children with acute lymphoblastic leukemia (ALL) are at increased risk of vitamin D deficiency, which might make them more susceptible to developing adverse events. Previous studies showed that low vitamin D levels were associated with an increased inflammatory mucosal state and impaired mucosal tissue barriers. We examined the prevalence of vitamin D deficiency and studied the association between vitamin D levels and methotrexate (MTX)-induced oral mucositis in pediatric ALL.

Methods We assessed 25-hydroxyvitamin $\mathrm{D}\left(25(\mathrm{OH}) \mathrm{D}_{3}\right)$ and 24,25-dihydroxyvitamin $\mathrm{D}\left(24,25(\mathrm{OH})_{2} \mathrm{D}_{3}\right)$ levels in 99 children with ALL before the start of $4 \times 5 \mathrm{~g} / \mathrm{m}^{2}$ high-dose methotrexate (HD-MTX) (T0) and in 81/99 children after discontinuation of HD-MTX (T1). Two cutoff values for vitamin D deficiency exist: $25(\mathrm{OH}) \mathrm{D}_{3}$ levels $<30$ and $<50 \mathrm{nmol} / \mathrm{L}$. Oral mucositis was defined as grade $\geq 3$ according to the National Cancer Institute Criteria.

Results Vitamin D deficiency occurred in respectively $8 \%(<30 \mathrm{nmol} / \mathrm{L})$ and $33 \%(<50 \mathrm{nmol} / \mathrm{L})$ of the patients at T0, and more frequently in children $>4$ years of age as compared to children between 1 and 4 years of age. A decrease in $25(\mathrm{OH}) \mathrm{D}_{3}$ levels during HD-MTX therapy was associated with developing severe oral mucositis (OR 1.6; 95\% CI [1.1-2.4]). 25(OH) $\mathrm{D}_{3}$ and $24,25(\mathrm{OH})_{2} \mathrm{D}_{3}$ levels at $\mathrm{T} 0$ and the change in $24,25(\mathrm{OH})_{2} \mathrm{D}_{3}$ levels during therapy were not associated with the development of severe oral mucositis.

Conclusions This study showed that vitamin D deficiency occurs frequently in pediatric ALL patients above the age of 4 years. A decrease in $25(\mathrm{OH}) \mathrm{D}_{3}$ levels during MTX therapy was observed in children with ALL that developed severe oral mucositis.
\end{abstract}

Keywords Vitamin D · Acute lymphoblastic leukemia · Oral mucositis · Methotrexate

\section{Abbreviations}

ALL Acute lymphoblastic leukemia

BMI Body mass index
HD-MTX High-dose methotrexate

NCI National Cancer Institute

VDBP Vitamin D-binding proteins
Electronic supplementary material The online version of this article (https://doi.org/10.1007/s00520-018-4312-0) contains supplementary material, which is available to authorized users.

N. Oosterom

N.Oosterom@ prinsesmaximacentrum.nl

1 Princess Máxima Center for Pediatric Oncology, P.O. 85090, 3508 AB Utrecht, The Netherlands

2 Department of Clinical Chemistry, Erasmus MC University Medical Center, Rotterdam, The Netherlands

3 University Medical Center Utrecht, Utrecht, The Netherlands

4 Endocrine Laboratory, Department of Clinical Chemistry, VU University Medical Center, Amsterdam, The Netherlands
5 Department of Clinical Chemistry, VU University Medical Center, Amsterdam, The Netherlands

6 Department of Pediatric Oncology, University Medical Center Groningen, Groningen, The Netherlands

7 Laboratory for Endocrinology, Academic Medical Center, Amsterdam, The Netherlands

8 Department of Pediatric Oncology/Hematology, Erasmus Medical Center-Sophia's Children's Hospital, Rotterdam, The Netherlands 


\section{Introduction}

Five-year survival rates of children with acute lymphoblastic leukemia (ALL) have currently reached $90 \%$ in developed countries $[1,2]$. As treatment outcome has improved substantially, more research focuses on strategies to reduce toxic side effects from drugs such as methotrexate (MTX). Identifying risk factors of high-dose methotrexate (HD-MTX)-induced adverse events, such as oral mucositis, would be valuable to develop preventive interventions. We previously showed that oral mucositis occurs in $20 \%$ of pediatric ALL patients during HD-MTX $\left(5 \mathrm{~g} / \mathrm{m}^{2}\right)$ courses. [3]

A relation between vitamin D deficiency and chemotherapy-induced oral mucositis has been suggested in a case report of a 59-year-old patient with breast carcinoma receiving a treatment regimen of docetaxel, carboplatin, and trastuzumab [4]. Vitamin D is a fat-soluble vitamin and important hormone involved in many physiological processes in the human body, such as bone mineralization, insulin regulation, and immune regulation [5-7]. Previous studies showed that the vitamin $\mathrm{D}$ receptor is expressed in the mucosa and that a relation exists between low vitamin D levels and an increased inflammatory mucosal state and impaired mucosal tissue barriers [8-10]. The main sources of vitamin D are production in the skin through sunlight exposure, diet, and vitamin D supplements [7, 11]. Vitamin $\mathrm{D}\left(\mathrm{D}_{2}\right.$ and $\left.\mathrm{D}_{3}\right)$ is hydroxylated in the liver to 25-hydroxyvitamin D $(25(\mathrm{OH}) \mathrm{D})$ and is converted into 1,25-dihydroxyvitamin D $\left(1,25(\mathrm{OH})_{2} \mathrm{D}\right)$ or into 24,25 -dihydroxyvitamin $\mathrm{D}$ $\left(24,25(\mathrm{OH})_{2} \mathrm{D}_{3}\right)$.

Children with ALL may be at increased risk of vitamin D deficiency due to impaired sun exposure and impaired vitamin intake [12]. A retrospective study in 86 pediatric cancer patients with a median age of 7 years revealed vitamin D deficiency in $63 \%$ at diagnosis [13]. In childhood cancer survivors, vitamin $\mathrm{D}$ deficiency was more prevalent than in control subjects $[14,15]$. Declining vitamin D levels during anthracycline- and docetaxel-based chemotherapy regimens were observed in 20 adult breast cancer patients [16]. In adult cancer patients, no difference in chemotherapy-related toxicity, including mucositis, was found between patients with and without vitamin D deficiency [17]. However, this study cohort consisted of patients with various malignancies and different treatment regimens and numbers were too small. Until now, no studies have examined the possible role of vitamin D in relation to MTX-induced oral mucositis in pediatric cancer patients.

This prospective study aimed to determine the prevalence of vitamin D deficiency after ALL induction therapy before the start of HD-MTX treatment, and to examine whether vitamin D levels and a change in vitamin D levels during highdose MTX treatment were associated with the development of MTX-induced mucositis in children with ALL.

\section{Materials and methods}

\section{Patient selection and toxicity evaluation}

Pediatric ALL patients (1-19 years) treated according to the standard and medium risk arms of the Dutch Childhood Oncology Group ALL-10 protocol between 2004 and 2012 were eligible for this study [2]. The study was approved by the Medical Ethical Committee (MEC-2005-358) and written informed consent was obtained from patients and their parents. Detailed information on this protocol and cohort has been previously described [3]. HD-MTX-induced oral mucositis was used as clinical endpoint in this study and was scored prospectively before, during, and after each high-dose MTX course and at the end of protocol $\mathrm{M}$ according to the National Cancer Institute (NCI) Common Terminology Criteria for Adverse Events v.3.0 score system by trained clinicians and nurse specialists on a standardized clinical record forms [18]. Clinically relevant oral mucositis was defined as NCI grade $\geq$ 3 (confluent ulcerations, bleeding with minor trauma; symptomatic and unable to adequately aliment or hydrate orally). According to the guideline of the Dutch Health Council, $10 \mu \mathrm{g}$ vitamin D supplementation per day is recommended in children until the age of 4 years [19].

\section{Vitamin D levels: $25(\mathrm{OH}) \mathrm{D}_{2}, 25(\mathrm{OH}) \mathrm{D}_{3}$, and $24,25(\mathrm{OH})_{2} \mathrm{D}_{3}$}

Peripheral blood samples for measurement of vitamin D levels were collected before the start of protocol M (T0) and 2 weeks after discontinuation of protocol M (T1) (Supplemental Fig. 1). All serum samples were stored at $-80{ }^{\circ} \mathrm{C}$ and analyzed collectively. The $25(\mathrm{OH}) \mathrm{D}_{2}, 25(\mathrm{OH}) \mathrm{D}_{3}$, and $24,25(\mathrm{OH})_{2} \mathrm{D}_{3}$ levels were analyzed using isotope dilution liquid chromatography tandem mass spectrometry (ID-LCMS/MS), with detection limits for the three compounds of $0.36,1.19$, and $0.12 \mathrm{nmol} / \mathrm{L}$, respectively. Intra-assay coefficients of variation (CVs) were 3,3 , and $5 \%$, while inter-assay CVs were 6,6 , and $9 \%$ for $25(\mathrm{OH}) \mathrm{D}_{2}, 25(\mathrm{OH}) \mathrm{D}_{3}$, and $24,25(\mathrm{OH})_{2} \mathrm{D}_{3}$, respectively. The $25(\mathrm{OH}) \mathrm{D}_{3} / 24,25(\mathrm{OH})_{2} \mathrm{D}_{3}$ ratio was calculated as previously described [20]. Vitamin D deficiency was defined as both $25(\mathrm{OH}) \mathrm{D}_{3}$ levels of $<30$ and of $<50 \mathrm{nmol} / \mathrm{L}$, as controversy exists on the correct cutoff value $[19,21,22]$.

\section{Statistical analysis}

The chi-square test was used to compare differences in the prevalence of vitamin D deficiency between patients with and patients without oral mucositis. The independent $t$ test (normally distributed variables) and Mann-Whitney $U$ test (skewed variables) were used to compare mean or median $25(\mathrm{OH}) \mathrm{D}_{2}, 25(\mathrm{OH}) \mathrm{D}_{3}$, and $24,25(\mathrm{OH})_{2} \mathrm{D}_{3}$ levels and the 
$25(\mathrm{OH}) \mathrm{D}_{3} / 24,25(\mathrm{OH})_{2} \mathrm{D}_{3}$ ratio at $\mathrm{T} 0$ and the change in these levels between $\mathrm{T} 0$ and $\mathrm{T} 1$ (delta $\mathrm{T} 1-\mathrm{T} 0$ ) in patients with and without oral mucositis. A $p$ value $<0.05$ was considered significant. Logistic regression analysis was used to examine the strength of the associations between $25(\mathrm{OH}) \mathrm{D}_{2}, 25(\mathrm{OH}) \mathrm{D}_{3}$, and $24,25(\mathrm{OH})_{2} \mathrm{D}_{3}$ levels and the $25(\mathrm{OH}) \mathrm{D}_{3} / 24,25(\mathrm{OH})_{2} \mathrm{D}_{3}$ ratio (T0 and delta T1-T0) and oral mucositis. We performed univariable logistic regression analyses with the vitamin D indicators as independent variables and oral mucositis as a dependent variable. Subsequently, associations were adjusted for possible confounders, such as age, sex, season, ALL risk group, ALL immunophenotype, and body mass index (BMI), in a multivariable logistic regression analysis. Possible confounders were included when they had a $p$ value $<0.20$ in univariable analysis with both the determinant (vitamin D levels) and the outcome (oral mucositis NCI grade $\geq 3$ ) and when they changed the $\beta$ in logistic regression analysis $>10 \%$ $[23,24]$. All analyses of the association between the change in vitamin D levels and the development of oral mucositis were corrected for vitamin D levels at $\mathrm{T} 0$.

\section{Results}

\section{Patient characteristics}

In total, 99 children with ALL were eligible for this study (Fig. 1). We obtained samples for analysis in all patients at baseline (T0) and in 81/99 patients after discontinuation of HD-MTX (T1). Baseline characteristics of the patients are summarized in Table 1. Twenty-three patients (23\%) developed MTX-induced oral mucositis NCI grade $\geq 3$ during treatment.

\section{Possible confounders}

In univariable analysis, none of the possible confounders met the criteria for inclusion in the multivariate models (Supplemental Table 1a $+1 b$ ). In univariable analysis, $25(\mathrm{OH}) \mathrm{D}_{3}$ levels were significantly higher (mean $\pm \mathrm{SE}$, $76.1 \pm 3.2 \mathrm{nmol} / \mathrm{L}$ ) in the age category " $1-4$ years" versus the age category " $>4$ years" (mean $\pm \mathrm{SE}, 52.8 \pm 2.9 \mathrm{nmol} /$ L) $(p<0.001)$. Furthermore, $25(\mathrm{OH}) \mathrm{D}_{3}$ levels were significantly lower in patients with a high $\mathrm{BMI} \geq 25$ (mean $\pm \mathrm{SE}$, $21.3 \pm 6.1)$ versus patients with a normal BMI 18-25 (mean \pm SE, $58.8 \pm 4.4$ ) and patients with a low BMI < 18 (mean \pm SE, $68.5 \pm 3.1)(p<0.001)$. However, age and BMI were not associated with the development of severe oral mucositis and did not change the $\beta$ in logistic regression analysis $>10 \%$ and were therefore not considered possible confounders in this study.
Vitamin D levels and vitamin D deficiency in children with ALL before the start of HD-MTX treatment (TO)

Levels of $25(\mathrm{OH}) \mathrm{D}_{2}$ (median $0.7 \mathrm{nmol} / \mathrm{L}$ [0.4-1.3]), $25(\mathrm{OH}) \mathrm{D}_{3}$ (mean $63.1 \pm 2.4 \mathrm{nmol} / \mathrm{L}$ ) and $24,25(\mathrm{OH})_{2} \mathrm{D}_{3}$ (median $5.2 \mathrm{nmol} / \mathrm{L}[2.8-7.4])$ and the $25(\mathrm{OH}) \mathrm{D}_{3} / 24,25(\mathrm{OH})_{2} \mathrm{D}_{3}$ ratio (mean $13.6 \pm 0.5$ ) at $\mathrm{T} 0$ are reported in Table 2. Vitamin D deficiency was present in $8 \%$ of the children using a cutoff value of $25(\mathrm{OH}) \mathrm{D}_{3}<30 \mathrm{nmol} / \mathrm{L}$ (age category " $1-4$ years": $2 \%$ versus " $>4$ years": $13 \%$ ) and in $33 \%$ of children using a cutoff value of $25(\mathrm{OH}) \mathrm{D}_{3}<50 \mathrm{nmol} / \mathrm{L}$ (age category " 1 4 years": $11 \%$ versus " $>4$ years": $51 \%$ ).

\section{Vitamin D levels at TO in relation to development of HD-MTX-induced oral mucositis}

In 23/99 samples, $25(\mathrm{OH}) \mathrm{D}_{2}$ levels were below the detection limit of $0.36 \mathrm{nmol} / \mathrm{L}$. In the remaining 76 samples, median levels of $25(\mathrm{OH}) \mathrm{D}_{2}$ at $\mathrm{T} 0$ were low $(0.7 \mathrm{nmol} / \mathrm{L}$ [0.4-1.3]) and were therefore not analyzed in relation to MTX-induced oral mucositis as these levels were not clinically relevant (Table 2). We used vitamin D deficiency with a cutoff value $<50 \mathrm{nmol} / \mathrm{L}$ in further analyses as vitamin $\mathrm{D}$ deficiency with a cutoff value $<30 \mathrm{nmol} / \mathrm{L}$ could not be analyzed, because the number of cases in the vitamin $\mathrm{D}$ deficient group was too small. 25(OH) $\mathrm{D}_{3}$ levels, $24,25(\mathrm{OH})_{2} \mathrm{D}_{3}$ levels, and the $25(\mathrm{OH}) \mathrm{D}_{3} / 24,25(\mathrm{OH})_{2} \mathrm{D}_{3}$ ratio analyzed as a continuous variable at T0 were not significantly associated with severe MTX-induced oral mucositis (Table 3).

\section{Change in vitamin D levels between T0 and T1 in relation to the development of HD-MTX-induced oral mucositis}

$25(\mathrm{OH}) \mathrm{D}_{3}$ levels decreased significantly between $\mathrm{T} 0$ and $\mathrm{T} 1$ during high-dose MTX therapy in patients with oral mucositis NCI grade $\geq 3(-9.6 \pm 14.3 \mathrm{nmol} / \mathrm{L})$ as compared to patients without oral mucositis NCI grade $\geq 3(+2.4 \pm 17.2 \mathrm{nmol} / \mathrm{L})$ (Fig. $2+$ Table $4, p$ value $=0.012$ ). A decrease of $25(\mathrm{OH}) \mathrm{D}_{3}$ level of $10 \mathrm{nmol} / \mathrm{L}$ during HD-MTX therapy increased the odds of developing severe MTX-induced oral mucositis 1.6-fold (OR 1.63 [1.11-2.38], $p$ value $<0.012$, Table 4). Changes in levels of $24,25(\mathrm{OH})_{2} \mathrm{D}_{3}$ and the $25(\mathrm{OH}) \mathrm{D}_{3} / 24,25(\mathrm{OH})_{2} \mathrm{D}_{3}$ ratio between $\mathrm{T} 0$ and $\mathrm{T} 1$ were not significantly associated with the development of MTX-induced oral mucositis (Table 4).

\section{Discussion}

In this study, vitamin $\mathrm{D}$ deficiency occurred in respectively $8 \%(<30 \mathrm{nmol} / \mathrm{L})$ and $33 \%(<50 \mathrm{nmol} / \mathrm{L})$ of the patients before the start of HD-MTX therapy, and more frequently in 
Fig. 1 Flowchart of patient inclusion. ALL, acute lymphoblastic leukemia; HDMTX, high-dose methotrexate; DCOG, Dutch Childhood Oncology Group; SNP, singlenucleotide polymorphism; $n$, number of patients; * one patient had neurological damage before the start of HD-MTX treatment, one patients was transferred to another hospital, one patient had an adjusted protocol due to a SPINKS mutation, and one patient was initially treated otherwise due to another diagnosis

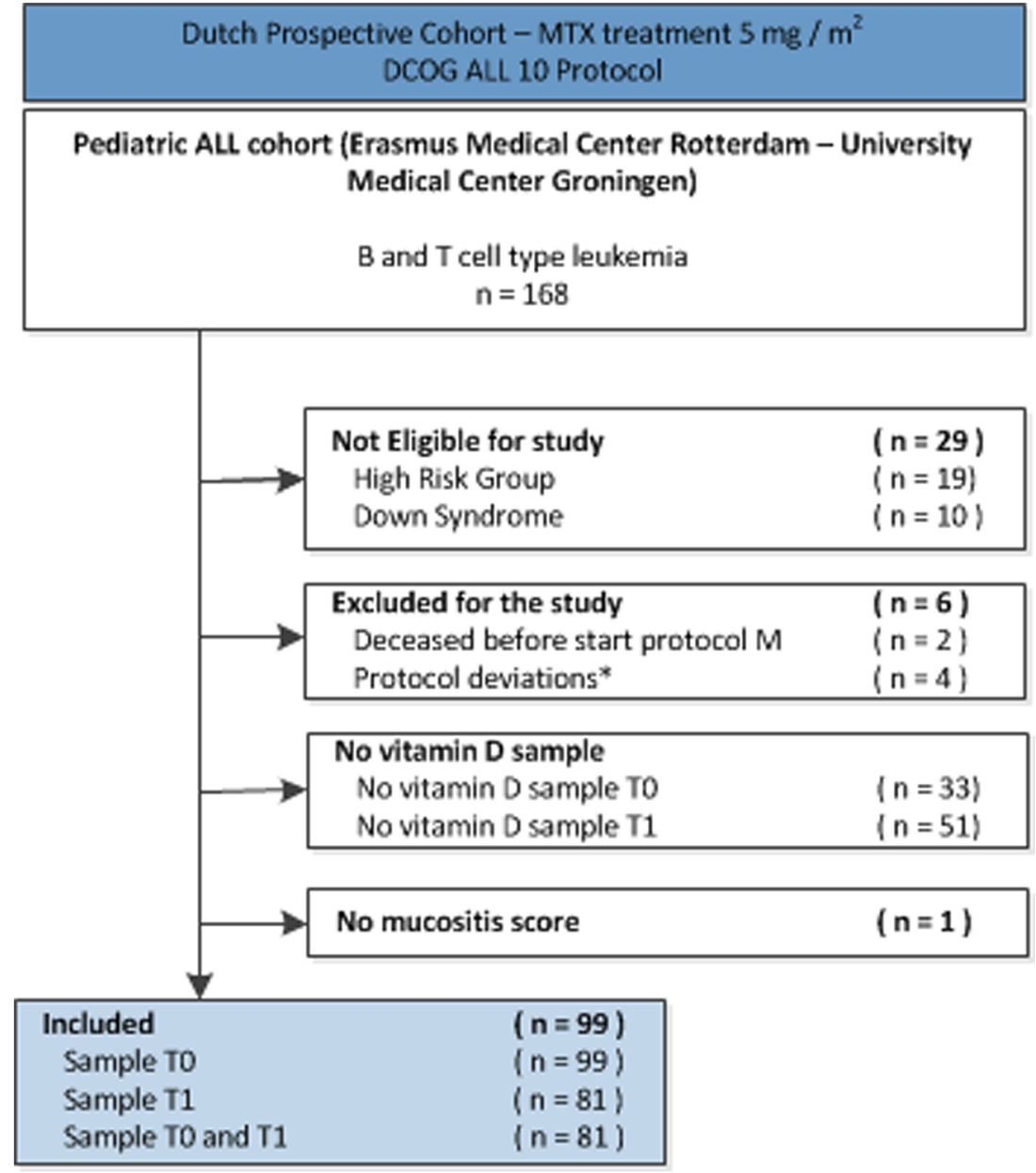

children older than 4 years of age. Vitamin D levels before the start of high-dose MTX treatment were not associated with developing MTX-induced oral mucositis, but during MTX

Table 1 Patient characteristics $(n=99)$

\begin{tabular}{lll}
\hline Median age at diagnosis, years (range) & 5.7 & $(1.4-18.1)$ \\
$\quad$ Sex, $n(\%)$ & 55 & $(56 \%)$ \\
$\quad$ Female & 44 & $(44 \%)$ \\
$\quad$ Male & & \\
Risk group ALL treatment, $n(\%)$ & 28 & $(28 \%)$ \\
$\quad$ Standard risk & 71 & $(72 \%)$ \\
$\quad$ Medium risk & & \\
Immunophenotype ALL, $n(\%)$ & 85 & $(86 \%)$ \\
$\quad$ B-lineage & 14 & $(14 \%)$ \\
$\quad$ T-lineage & 17.3 & $(13.2-31.5)$ \\
Median BMI, kg/m ${ }^{2}$ (range) & \\
$\quad$ Mucositis, $n(\%)$ & & \\
$\quad$ Mucositis $\geq$ NCI grade 3 & 23 & $(23 \%)$ \\
\hline
\end{tabular}

NCI National Cancer Institute

${ }^{\mathrm{a}} \mathrm{BMI}$ in eight patients missing therapy a decrease in $25(\mathrm{OH}) \mathrm{D}_{3}$ levels was observed in children with ALL that developed severe oral mucositis.

Currently, no consensus exists on optimal vitamin D serum levels in children. In children, both $25(\mathrm{OH}) \mathrm{D}$ levels < $30 \mathrm{nmol} / \mathrm{L}$ and levels $<50 \mathrm{nmol} / \mathrm{L}$ have been defined as vitamin D deficiency $[21,22]$. Therefore, we reported vitamin D levels with both cutoff values of $<30$ and $<50 \mathrm{nmol} / \mathrm{L}$. Using the cutoff value of $<50 \mathrm{nmol} / \mathrm{L}$ in our cohort, $11 \%$ of the children aged 1-4 years was vitamin D deficient compared to $51 \%$ of the children aged $>4$ years, suggesting that parents and/or caregivers supplemented the children in the younger age category according to the recommendations of the National Health Council [19]. Previous literature showed that vitamin D deficiency ( $<50 \mathrm{nmol} / \mathrm{L}$ ) occurred in $30 \%$ of Dutch children in the general population at the age of 6 years [25]. Our data showed that in the age category "5-7 years," 53\% (10/19) of pediatric ALL patients was deficient. This higher rate of vitamin D deficiency compared to the general population may be due to impaired sun exposition and less intake of vitamin D.

Our study showed a decrease in $25(\mathrm{OH}) \mathrm{D}_{3}$ levels during MTX therapy in children with ALL developing oral mucositis compared to children without oral mucositis, whereas vitamin 
Table 2 Vitamin D levels in pediatric ALL patients at the start of high-dose MTX treatment (T0)

\begin{tabular}{|c|c|c|c|c|}
\hline & & Levels (nmol/L) & \multicolumn{2}{|c|}{ Levels per age category $(\mathrm{nmol} / \mathrm{L})$} \\
\hline \multirow[t]{2}{*}{$25(\mathrm{OH}) \mathrm{D}_{2}$} & Median (IQR) & $0.7(0.4-1.3)$ & $1-4$ years & $0.5(0.4-1.2)$ \\
\hline & & & $>4$ years & $1.0(0.5-1.4)$ \\
\hline \multirow[t]{2}{*}{$25(\mathrm{OH}) \mathrm{D}_{3}$} & Mean $\pm \mathrm{SE}$ & $63.1 \pm 2.4$ & $1-4$ years & $76.1 \pm 3.2$ \\
\hline & & & $>4$ years & $52.8 \pm 2.9$ \\
\hline \multirow[t]{3}{*}{$24,25(\mathrm{OH})_{2} \mathrm{D}_{3}$} & Median (IQR) & $5.2(2.8-7.4)$ & $1-4$ years & $6.4(4.6-8.5)$ \\
\hline & & & $>4$ years & $4.2(2.2-6.4)$ \\
\hline & & Ratio & \multicolumn{2}{|c|}{ Ratio per age category } \\
\hline \multirow[t]{3}{*}{$25(\mathrm{OH}) \mathrm{D}_{3} / 24,25(\mathrm{OH})_{2} \mathrm{D}_{3}$ ratio } & Mean $\pm \mathrm{SE}$ & $13.6 \pm 0.5$ & $1-4$ years & $12.8 \pm 0.7$ \\
\hline & & & $>4$ years & $14.2 \pm 0.7$ \\
\hline & & Vitamin D deficiency, $n(\%)^{\mathrm{a}}$ & \multicolumn{2}{|c|}{ Vitamin D deficiency per age category, $n(\%)^{\mathrm{b}}$} \\
\hline \multirow[t]{4}{*}{$25(\mathrm{OH}) \mathrm{D}_{3}$} & $<30 \mathrm{nmol} / \mathrm{L}$ & $8(8 \%)$ & $1-4$ years & $1(2 \%)$ \\
\hline & & & $>4$ years & $7(13 \%)$ \\
\hline & $<50 \mathrm{nmol} / \mathrm{L}$ & $33(33 \%)$ & $1-4$ years & $5(11 \%)$ \\
\hline & & & $>4$ years & $28(51 \%)$ \\
\hline
\end{tabular}

$I Q R$ interquartile range, $S E$ standard error of the mean

${ }^{\text {a }}$ Percentage of total study group $(n=99)$

b Percentages within age group " $1-4$ years" $(n=44)$ and age group " $>4$ years" $(n=55)$

D levels before the start of MTX therapy were not associated with the development of oral mucositis. In this study, we were not able to verify whether a decrease in vitamin D levels preceded the occurrence of oral mucositis or vice versa. A probable explanation could be that patients suffering from severe oral mucositis are often admitted to the hospital where they have a more impaired intake, have less sunlight exposure, and might have impaired vitamin D uptake due to gastrointestinal mucositis compared to patients without oral mucositis, causing a decrease in vitamin D levels. Subsequently, a decrease in vitamin D levels may lead to an increased inflammatory state of the mucosa. The pathobiology of chemotherapy-related oral mucositis is not well understood, but is known to include an inflammatory part, in which both cytokine release of TNF $\alpha$, IL-6, and IL- $1 \beta$ and cellular infiltration of immune cells in the mucosa play a role [26]. Several studies have implicated a relation between low vitamin D levels and low vitamin D receptor expression and the development of an increased inflammatory response in the mucosa, such as in inflammatory bowel disease, by modulating $\mathrm{T}$ cell receptor responses and cytokine release [8, 27]. Furthermore, vitamin $\mathrm{D}$ deficiency has been implicated to play a role in tissue barrier defects in the gastro-intestinal system [9, 28]. Therefore, it could very well be that decreasing vitamin D
Table 3 Vitamin D levels at T0 in relation to HD-MTX-induced oral mucositis (NCI grade $\geq 3$ )

\begin{tabular}{|c|c|c|c|c|c|}
\hline & $\begin{array}{l}\text { Mucositis-no } \\
n=76\end{array}$ & $\begin{array}{l}\text { Mucositis-Yes } \\
n=23\end{array}$ & $p$ value & OR & $95 \% \mathrm{CI}$ \\
\hline \multicolumn{6}{|c|}{$25(\mathrm{OH}) \mathrm{D}_{3}, \mathrm{nmol} / \mathrm{L}$} \\
\hline Mean \pm SE & $62.3 \pm 3.0$ & $66.0 \pm 3.7$ & 0.528 & 1.006 & $(0.987-1.026)$ \\
\hline \multicolumn{6}{|l|}{$25(\mathrm{OH}) \mathrm{D}_{3}$} \\
\hline$<30 \mathrm{nmol} / \mathrm{L}$ & $8(100 \%)$ & $0(0 \%)$ & a & a & a \\
\hline$\geq 30 \mathrm{nmol} / \mathrm{L}$ & $68(75 \%)$ & $23(25 \%)$ & & & \\
\hline$<50 \mathrm{nmol} / \mathrm{L}$ & $28(85 \%)$ & $5(15 \%)$ & 0.178 & 2.100 & $(0.703-6.277)$ \\
\hline$\geq 50 \mathrm{nmol} / \mathrm{L}$ & $48(73 \%)$ & $18(27 \%)$ & & & \\
\hline \multicolumn{6}{|c|}{$24,25(\mathrm{OH})_{2} \mathrm{D}_{3}, \mathrm{nmol} / \mathrm{L}$} \\
\hline Median (IQR) & $5.3(2.7-7.3)$ & $4.8(4.0-8.3)$ & 0.494 & 1.047 & $(0.906-1.210)$ \\
\hline \multicolumn{6}{|c|}{$25(\mathrm{OH}) \mathrm{D}_{3} / 24,25(\mathrm{OH})_{2} \mathrm{D}_{3}$ ratio } \\
\hline Mean $\pm \mathrm{SE}$ & $13.8 \pm 0.6$ & $12.8 \pm 0.9$ & 0.401 & 0.957 & $(0.864-1.060)$ \\
\hline
\end{tabular}

$I Q R$ interquartile range, $S E$ standard error of the mean

${ }^{\text {a }}$ Power too low to perform statistical analysis 
$25(\mathrm{OH}) \mathrm{D}_{3}$ levels at $\mathrm{TO}$ and $\mathrm{T} 1$ in patients with and without oral mucositis

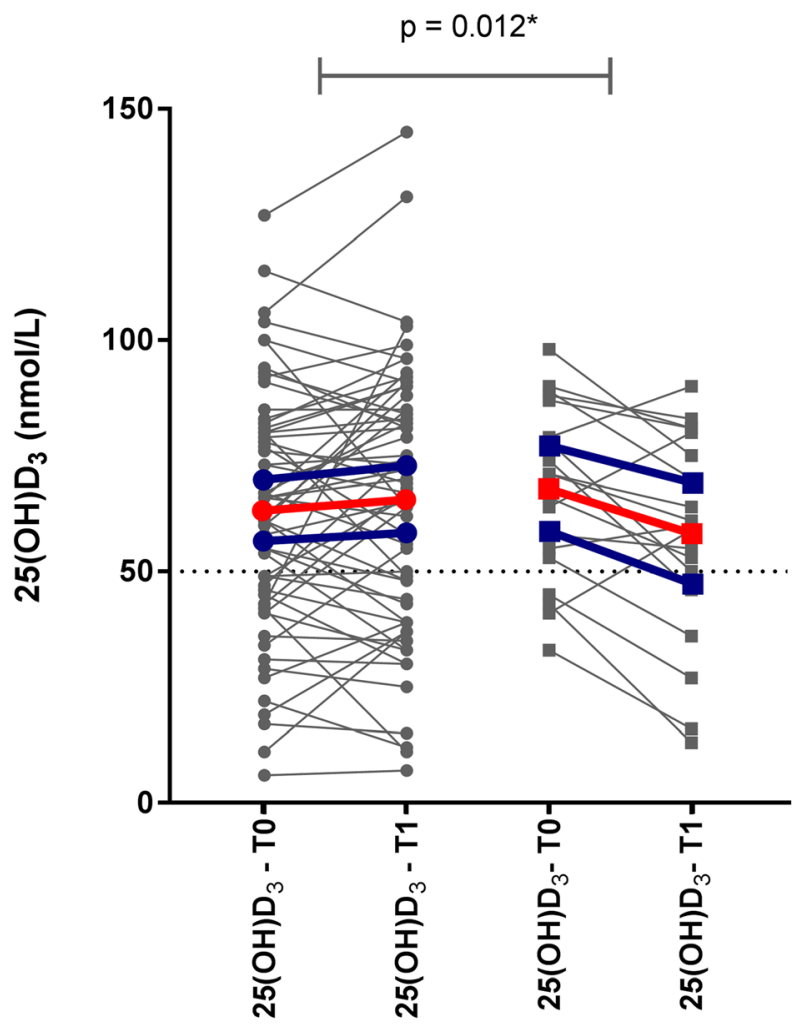

\section{Mucositis - No Mucositis - Yes}

Fig. $225(\mathrm{OH}) \mathrm{D}_{3}$ levels at $\mathrm{T} 0$ and $\mathrm{T} 0$ in relation to the development of oral mucositis. $25(\mathrm{OH}) \mathrm{D}_{3}$ levels at $\mathrm{T} 0$ and $\mathrm{T} 1$ in individual patients with (yes, $n=62$ ) and without (no, $n=19$ ) mucositis; the red lines indicate the mean $25(\mathrm{OH}) \mathrm{D}_{3}$ levels at $\mathrm{T} 0$ and $\mathrm{T} 1$ of all patients; the blue lines indicate the $95 \%$ confidence interval; the dotted line indicates the cutoff value of vitamin $\mathrm{D}$ deficiency at $25(\mathrm{OH}) \mathrm{D}_{3}$ levels $<50 \mathrm{nmol} / \mathrm{L}$. levels aggravate the course of oral mucositis. This needs further investigation as we did not have data on the length of the mucositis period or on inflammatory cytokine levels.

We showed that $25(\mathrm{OH}) \mathrm{D}_{2}$ levels were often below $(n=$ $23)$ and near $(n=76)$ the detection limit in children with ALL. This is most likely due to the fact that over-the-counter supplements in the Netherlands contain $25(\mathrm{OH}) \mathrm{D}_{3}$ and the relatively small source of plant-derived $25(\mathrm{OH}) \mathrm{D}_{2}$ will not lead to substantial plasma concentrations. As levels were very low, it was not statistically possible and clinically relevant to analyze these levels in relation to the development of MTX-induced oral mucositis.

Although $1,25(\mathrm{OH})_{2} \mathrm{D}$ is known as the active vitamin $\mathrm{D}$ metabolite, it is a poor indicator of overall vitamin $\mathrm{D}$ status as serum $1,25(\mathrm{OH})_{2} \mathrm{D}$ is often increased in patients with vitamin $\mathrm{D}$ deficiency due to secondary hyperparathyroidism [29]. Until recently, $24,25(\mathrm{OH})_{2} \mathrm{D}_{3}$ was considered an inactive metabolite or degradation product of $25(\mathrm{OH}) \mathrm{D}$. However, several reports suggested that $24,25(\mathrm{OH})_{2} \mathrm{D}_{3}$ possesses biological activity and that $24,25(\mathrm{OH})_{2} \mathrm{D}_{3}$ levels and the $25(\mathrm{OH}) \mathrm{D} / 24,25(\mathrm{OH})_{2} \mathrm{D}$ ratio reflect the vitamin $\mathrm{D}$ status [20, 30-33].

High BMI $(\geq 25)$ was present in four patients and these patients had very low $25(\mathrm{OH}) \mathrm{D}_{3}$ levels compared to patients with a normal BMI and an underweight BMI. This is in line with previous literature that showed that vitamin D deficiency occurs more frequently in obese cancer patients [34]. Proposed underlying mechanisms of this phenomenon include lack of sunlight due to less physical activity in obese patients and less bio-availability due to deposition of vitamin $\mathrm{D}$ in subcutaneous fat depots $[35,36]$.

Another important factor to take into account in future studies is the bio-availability of vitamin D. Vitamin D is largely bound to vitamin D-binding proteins (VDBP) and albumin. Lower levels of VDBP and albumin increase bio-availability

Table 4 Change vitamin D levels in relation to HD-MTX-induced oral mucositis (NCI grade $\geq 3$ )

\begin{tabular}{|c|c|c|c|c|c|c|}
\hline & $\begin{array}{l}\text { Mucositis-no } \\
n=62\end{array}$ & $\begin{array}{l}\text { Mucositis-yes } \\
n=19\end{array}$ & $p$ value & $p$ value corrected ${ }^{\mathrm{a}}$ & OR $(95 \% \mathrm{CI})$ & $1 / \mathrm{OR}(95 \% \mathrm{CI})^{\mathrm{b}}$ \\
\hline \multicolumn{7}{|c|}{ Delta $25(\mathrm{OH}) \mathrm{D}_{3}, \mathrm{nmol} / \mathrm{L}$} \\
\hline Mean \pm SE & $2.4 \pm 2.2$ & $-9.6 \pm 3.3$ & $0.007 *$ & $0.012 *$ & $\begin{array}{l}\text { Per } 1 \mathrm{nmol} / \mathrm{L}, 0.953(0.917-0.989) \\
\text { Per } 10 \mathrm{nmol} / \mathrm{L}, 0.615(0.421-0.899)\end{array}$ & $\begin{array}{l}1.05(1.01-1.09) \\
1.63(1.11-2.38)\end{array}$ \\
\hline \multicolumn{7}{|c|}{ Delta $24,25(\mathrm{OH})_{2} \mathrm{D}_{3}, \mathrm{nmol} / \mathrm{L}$} \\
\hline Median (IQR) & $-0.1(-1.7-0.9)$ & $-1.2(-1.9-0.4)$ & 0.160 & 0.447 & Per $1 \mathrm{nmol} / \mathrm{L}, 0.912(0.721-1.155)$ & $1.10(0.87-1.39)$ \\
\hline \multicolumn{7}{|c|}{ Delta $25(\mathrm{OH}) \mathrm{D}_{3} / 24,25(\mathrm{OH})_{2} \mathrm{D}_{3}$ ratio } \\
\hline Mean $\pm \mathrm{SE}$ & $0.3 \pm 0.5$ & $0.6 \pm 0.8$ & 0.818 & 0.930 & $0.993(0.840-1.173)$ & $1.01(0.85-1.19)$ \\
\hline
\end{tabular}

$I Q R$ interquartile range, $S E$ standard error of the mean

$* p$ value $<0.05$

${ }^{\text {a }}$ Corrected for $25(\mathrm{OH}) \mathrm{D}_{3}, 24,25(\mathrm{OH})_{2} \mathrm{D}_{3}$, and $25(\mathrm{OH}) \mathrm{D}_{3} / 24,25(\mathrm{OH})_{2} \mathrm{D}_{3}$ ratio at $\mathrm{T} 0$ respectively in multivariable logistic regression model

${ }^{\mathrm{b}}$ We performed 1/OR $(95 \% \mathrm{CI})$ as we reported the analysis as an increased risk and not as a decreased risk of developing oral mucositis 
and therefore the same level of vitamin D could have a different biological meaning in patients with different levels of VDBP and albumin [30].

Strengths of this study are the prospective collection of samples and toxicity data and the accuracy of the vitamin metabolite measurements. Limitations are the fact that possible confounders, such as vitamin D supplementation, nutritional status, VDBP levels, and inflammatory markers, were not studied. These factors could be taken into account in future studies to get insight into a possible mechanism.

In conclusion, the prevalence of vitamin D deficiency was high in children with ALL above the age of 4 years. Although we did not find an association between low baseline vitamin D levels with MTX-induced oral mucositis in children with ALL, $25(\mathrm{OH}) \mathrm{D}_{3}$ levels decreased significantly during MTX therapy in patients with severe MTX-induced oral mucositis. This should be further examined as vitamin D supplementation is a very easy intervention.

Authors' contributions The laboratory work was performed by NFD. NO performed the statistical data analysis and drafted the manuscript under the supervision of SMFP and ACH. WJET, RP, and MvdH contributed to the design and recruitment of patients and the data and sample collection. All authors (NO, NFD, SGH, RdJ, WJET, RP, MvdHE, ACH, SMFP) were involved in the interpretation of data, drafting of the manuscript, and subsequent revisions. All authors have read and approved the final manuscript.

Funding This project was supported by Stichting Kinderen Kankervrij (KiKa errant nr. 197), Amstelveen, the Netherlands.

\section{Compliance with ethical standards}

The study was approved by the Medical Ethical Committee (MEC2005-358).

Conflict of interest The authors declare that they have no conflict of interest.

Open Access This article is distributed under the terms of the Creative Commons Attribution-NonCommercial 4.0 International License (http:// creativecommons.org/licenses/by-nc/4.0/), which permits any noncommercial use, distribution, and reproduction in any medium, provided you give appropriate credit to the original author(s) and the source, provide a link to the Creative Commons license, and indicate if changes were made.

\section{References}

1. Hunger SP, Lu X, Devidas M, Camitta BM, Gaynon PS, Winick NJ, Reaman GH, Carroll WL (2012) Improved survival for children and adolescents with acute lymphoblastic leukemia between 1990 and 2005: a report from the children's oncology group. J Clin Oncol Off J Am Soc Clin Oncol 30(14):1663-1669. https://doi.org/10. 1200/jco.2011.37.8018
2. Pieters R, de Groot-Kruseman H, Van der Velden V, Fiocco M, van den Berg H, de Bont E, Egeler RM, Hoogerbrugge P, Kaspers G, Van der Schoot E, De Haas V, Van Dongen J (2016) Successful therapy reduction and intensification for childhood acute lymphoblastic leukemia based on minimal residual disease monitoring: study ALL10 from the Dutch Childhood Oncology Group. J Clin Oncol Off J Am Soc Clin Oncol 34(22):2591-2601. https://doi.org/ 10.1200/jco.2015.64.6364

3. den Hoed MA, Lopez-Lopez E, te Winkel ML, Tissing W, de Rooij JD, Gutierrez-Camino A, Garcia-Orad A, den Boer E, Pieters R, Pluijm SM, de Jonge R, van den Heuvel-Eibrink MM (2015) Genetic and metabolic determinants of methotrexate-induced mucositis in pediatric acute lymphoblastic leukemia. Pharmacogenomics J 15(3):248-254. https://doi.org/10.1038/tpj. 2014.63

4. Fink M (2011) Vitamin D deficiency is a cofactor of chemotherapyinduced mucocutaneous toxicity and dysgeusia. J Clin Oncol Off J Am Soc Clin Oncol 29(4):e81-e82. https://doi.org/10.1200/jco. 2010.31.5317

5. Pludowski P, Holick MF, Pilz S, Wagner CL, Hollis BW, Grant WB, Shoenfeld Y, Lerchbaum E, Llewellyn DJ, Kienreich K, Soni M (2013) Vitamin D effects on musculoskeletal health, immunity, autoimmunity, cardiovascular disease, cancer, fertility, pregnancy, dementia and mortality - a review of recent evidence. Autoimmun Rev 12(10):976-989. https://doi.org/10.1016/j.autrev. 2013.02.004

6. Holick MF (2007) Vitamin D deficiency. N Engl J Med 357(3): 266-281. https://doi.org/10.1056/NEJMra070553

7. DeLuca HF (2004) Overview of general physiologic features and functions of vitamin D. Am J Clin Nutr 80(6 Suppl):1689s-1696s

8. Sun J (2010) Vitamin D and mucosal immune function. Curr Opin Gastroenterol 26(6):591-595. https://doi.org/10.1097/MOG. 0b013e32833d4b9f

9. Zhang YG, Wu S, Sun J (2013) Vitamin D, vitamin D receptor, and tissue barriers. Tissue Barriers 1(1):e23118. https://doi.org/10. 4161/tisb.23118

10. Li YC, Chen Y, Du J (2015) Critical roles of intestinal epithelial vitamin D receptor signaling in controlling gut mucosal inflammation. J Steroid Biochem Mol Biol 148:179-183. https://doi.org/10. 1016/j.jsbmb.2015.01.011

11. Holick MF (2006) Resurrection of vitamin D deficiency and rickets. J Clin Invest 116(8):2062-2072. https://doi.org/10.1172/jci29449

12. Ladas EJ, Orjuela M, Stevenson K, Cole PD, Lin M, Athale UH, Clavell LA, Leclerc JM, Michon B, Schorin MA, Welch JG, Asselin BL, Sallan SE, Silverman LB, Kelly KM (2016) Dietary intake and childhood leukemia: the Diet and Acute Lymphoblastic Leukemia Treatment (DALLT) cohort study. Nutrition 32(10): 1103-1109.e1101. https://doi.org/10.1016/j.nut.2016.03.014

13. Genc DB, Vural S, Yagar G (2016) The incidence of and factors associated with vitamin D deficiency in newly diagnosed children with cancer. Nutr Cancer 68(5):756-761. https://doi.org/10.1080/ 01635581.2016 .1180408

14. Sinha A, Avery P, Turner S, Bailey S, Cheetham T (2011) Vitamin D status in paediatric patients with cancer. Pediatr Blood Cancer 57(4):594-598. https://doi.org/10.1002/pbc.22963

15. Neville KA, Walker JL, Cohn RJ, Cowell CT, White CP (2015) The prevalence of vitamin D deficiency is higher in adult survivors of childhood cancer. Clin Endocrinol 82(5):657-662. https://doi.org/ 10.1111/cen.12721

16. Santini D, Galluzzo S, Vincenzi B, Zoccoli A, Ferraro E, Lippi C, Altomare V, Tonini G, Bertoldo F (2010) Longitudinal evaluation of vitamin D plasma levels during anthracycline- and docetaxelbased adjuvant chemotherapy in early-stage breast cancer patients. Ann Oncol 21(1):185-186. https://doi.org/10.1093/annonc/ mdp497 
17. Kitchen D, Hughes B, Gill I, O'Brien M, Rumbles S, Ellis P, Harper P, Stebbing J, Rohatgi N (2012) The relationship between vitamin $\mathrm{D}$ and chemotherapy-induced toxicity - a pilot study. Br J Cancer 107(1):158-160. https://doi.org/10.1038/bjc.2012.194

18. Trotti A, Colevas AD, Setser A, Rusch V, Jaques D, Budach V, Langer C, Murphy B, Cumberlin R, Coleman CN, Rubin P (2003) CTCAE v3.0: development of a comprehensive grading system for the adverse effects of cancer treatment. Semin Radiat Oncol 13(3):176-181. https://doi.org/10.1016/s1053-4296(03) 00031-6

19. Weggemans RM, Schaafsma G, Kromhout D (2009) Towards an adequate intake of vitamin D. An advisory report of the Health Council of the Netherlands. Eur J Clin Nutr 63(12):1455-1457. https://doi.org/10.1038/ejen.2009.67

20. Wagner D, Hanwell HE, Schnabl K, Yazdanpanah M, Kimball S, Fu L, Sidhom G, Rousseau D, Cole DE, Vieth R (2011) The ratio of serum 24,25 -dihydroxyvitamin $\mathrm{D}(3)$ to 25 -hydroxyvitamin $\mathrm{D}(3)$ is predictive of 25-hydroxyvitamin $\mathrm{D}(3)$ response to vitamin $\mathrm{D}(3)$ supplementation. J Steroid Biochem Mol Biol 126(3-5):72-77. https://doi.org/10.1016/j.jsbmb.2011.05.003

21. Munns CF, Shaw N, Kiely M, Specker BL, Thacher TD, Ozono K, Michigami T, Tiosano D, Mughal MZ, Makitie O, Ramos-Abad L, Ward L, DiMeglio LA, Atapattu N, Cassinelli H, Braegger C, Pettifor JM, Seth A, Idris HW, Bhatia V, Fu J, Goldberg G, Savendahl L, Khadgawat R, Pludowski P, Maddock J, Hypponen E, Oduwole A, Frew E, Aguiar M, Tulchinsky T, Butler G, Hogler W (2016) Global consensus recommendations on prevention and management of nutritional rickets. J Clin Endocrinol Metab 101(2): 394-415. https://doi.org/10.1210/jc.2015-2175

22. Misra M, Pacaud D, Petryk A, Collett-Solberg PF, Kappy M (2008) Vitamin $\mathrm{D}$ deficiency in children and its management: review of current knowledge and recommendations. Pediatrics 122(2):398417. https://doi.org/10.1542/peds.2007-1894

23. Maldonado G, Greenland S (1993) Simulation study of confounder-selection strategies. Am J Epidemiol 138(11):923-936

24. Budtz-Jorgensen E, Keiding N, Grandjean P, Weihe P (2007) Confounder selection in environmental epidemiology: assessment of health effects of prenatal mercury exposure. Ann Epidemiol 17(1):27-35. https://doi.org/10.1016/j.annepidem.2006.05.007

25. Tromp II, Franco OH, van den Hooven EH, Heijboer AC, Jaddoe VW, Duijts L, de Jongste JC, Moll HA, Kiefte-de Jong JC (2016) 25-Hydroxyvitamin D concentrations, asthma and eczema in childhood: the generation R study. Clin Nutr. https://doi.org/10.1016/j. clnu.2016.11.019

26. Sonis ST (2004) The pathobiology of mucositis. Nat Rev Cancer 4(4):277-284. https://doi.org/10.1038/nrc1318

27. Lim WC, Hanauer SB, Li YC (2005) Mechanisms of disease: vitamin D and inflammatory bowel disease. Nat Clin Pract Gastroenterol Hepatol 2(7):308-315. https://doi.org/10.1038/ ncpgasthep0215

28. Zhang YG, Wu S, Lu R, Zhou D, Zhou J, Carmeliet G, Petrof E, Claud EC, Sun J (2015) Tight junction CLDN2 gene is a direct target of the vitamin D receptor. Sci Rep 5:10642. https://doi.org/ $10.1038 /$ srep 10642

29. Holick MF (2009) Vitamin D status: measurement, interpretation, and clinical application. Ann Epidemiol 19(2):73-78. https://doi. org/10.1016/j.annepidem.2007.12.001

30. Jones G, Prosser DE, Kaufmann M (2012) 25-Hydroxyvitamin D24-hydroxylase (CYP24A1): its important role in the degradation of vitamin D. Arch Biochem Biophys 523(1):9-18. https://doi.org/ 10.1016/j.abb.2011.11.003

31. Wang TJ, Zhang F, Richards JB, Kestenbaum B, van Meurs JB, Berry D, Kiel DP, Streeten EA, Ohlsson C, Koller DL, Peltonen L, Cooper JD, O'Reilly PF, Houston DK, Glazer NL, Vandenput L, Peacock M, Shi J, Rivadeneira F, McCarthy MI, Anneli P, de Boer IH, Mangino M, Kato B, Smyth DJ, Booth SL, Jacques PF, Burke GL, Goodarzi M, Cheung CL, Wolf M, Rice K, Goltzman D, Hidiroglou N, Ladouceur M, Wareham NJ, Hocking LJ, Hart D, Arden NK, Cooper C, Malik S, Fraser WD, Hartikainen AL, Zhai G, Macdonald HM, Forouhi NG, Loos RJ, Reid DM, Hakim A, Dennison E, Liu Y, Power C, Stevens HE, Jaana L, Vasan RS, Soranzo N, Bojunga J, Psaty BM, Lorentzon M, Foroud T, Harris TB, Hofman A, Jansson JO, Cauley JA, Uitterlinden AG, Gibson Q, Jarvelin MR, Karasik D, Siscovick DS, Econs MJ, Kritchevsky SB, Florez JC, Todd JA, Dupuis J, Hypponen E, Spector TD (2010) Common genetic determinants of vitamin D insufficiency: a genome-wide association study. Lancet 376(9736):180-188. https://doi.org/10.1016/s0140-6736(10)60588-0

32. Carpenter TO, Keller M, Schwartz D, Mitnick M, Smith C, Ellison A, Carey D, Comite F, Horst R, Travers R, Glorieux FH, Gundberg CM, Poole AR, Insogna KL (1996) 24,25 Dihydroxyvitamin D supplementation corrects hyperparathyroidism and improves skeletal abnormalities in X-linked hypophosphatemic rickets - a clinical research center study. J Clin Endocrinol Metab 81(6):23812388. https://doi.org/10.1210/jcem.81.6.8964881

33. Weinstock-Guttman B, Zivadinov R, Qu J, Cookfair D, Duan X, Bang E, Bergsland N, Hussein S, Cherneva M, Willis L, HeininenBrown M, Ramanathan M (2011) Vitamin D metabolites are associated with clinical and MRI outcomes in multiple sclerosis patients. J Neurol Neurosurg Psychiatry 82(2):189-195. https://doi. org/10.1136/jnnp.2010.227942

34. Vashi PG, Trukova K, Lammersfeld CA, Braun DP, Gupta D (2010) Impact of oral vitamin D supplementation on serum 25hydroxyvitamin D levels in oncology. Nutr J 9:60. https://doi.org/ 10.1186/1475-2891-9-60

35. Lee P, Greenfield JR, Seibel MJ, Eisman JA, Center JR (2009) Adequacy of vitamin D replacement in severe deficiency is dependent on body mass index. Am J Med 122(11):1056-1060. https:// doi.org/10.1016/j.amjmed.2009.06.008

36. Florez H, Martinez R, Chacra W, Strickman-Stein N, Levis S (2007) Outdoor exercise reduces the risk of hypovitaminosis D in the obese. J Steroid Biochem Mol Biol 103(3-5):679-681. https:// doi.org/10.1016/j.jsbmb.2006.12.032 